\title{
Sheikh Burhanuddin's Cultural Da'wah System in Minangkabau
}

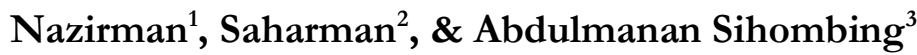 \\ ${ }^{123}$ UIN Imam Bonjol, Padang, Indonesia \\ *nazirman@uinib.ac.id
}

\begin{abstract}
This discourse describes Syekh Burbanuddin's cultural da'wah system in Minangkabau as one of the classical da'wah role models that have taken root and preserved to this day. This study aims to reveal the structure and system of da'wah built by Syekh Burbanuddin through a qualitative research method with a historical, descriptive analysis approach. The data collection technique used snowball sampling by taking locations in Ulakan Padang Pariaman, Kenagarian Puluik-Puluik and Kapujan Bayang Pesisir Selatan, Kenagarian Agarng Paynng Sekaki, Solok district, and Koto Tangah, Padang City. The research shows that Sheikh Burhanuddin's cultural da'wah system is integrated and has a multi-level da'wah pattern in the da'wah network known as the seven pillars of syattariyyah da'wah, including: Syekb Tuo Koto Tuo, Tuanku Qadi in Lubuk. Ipuh, Angku Qadi seven Koto (Toboh Karambia), Tuanku Qadhi Koto Gadang, Ampu Sarak in Sintuak, Tuanku Qadi Tobob Gadang, and Tuanku Qadi in Pakandangan. The seven pillars are representative reflections of the modeling of cultural da'wah in Minangkabau.
\end{abstract}

Keyword: da'wah system; cultural; seven pillars of da'wah.

\begin{abstract}
ABSTRAK
Diskursus ini mendekripsikan tentang sistem dakwah kultural Syekh Burhanuddin di Minangkabau sebagai salah satu rolemodel dakwah klasik yang mengakar dan tetap dilestarikan sampai saat ini. Penelitian bertujuan untuk mengungkap struktur dan sistem dakwah yang dibangun oleh Syekh Burhanuddin melalui metode penelitian kualitatif pendekatan historis dekskriptif analisis. Teknik pengumpulan data menggunakan snowball sampling dengan mengambil lokasi di Ulakan Padang Pariaman, Kenagarian Puluik-Puluik dan Kapujan Bayang Pesisir Selatan, Kenagarian Supayang Payung Sekaki kabupaten Solok, serta Koto Tangah Kota Padang. Penelitian menunjukkan bahwa sistem dakwah kultural Syekh Burhanuddin terintegrasi dan bercorak multi level dakwah dalam jejaring dakwah yang dikenal dengan tujuh pilar dakwah syattariyyah antara lain: Syekh Tuo Koto Tuo, Tuanku Qadi di Lubuk Ipuh, Angku Qadi tujuh Koto (Toboh Karambia), Tuanku Qadhi Koto Gadang, Ampu Sarak di Sintuak, Tuanku Qadi Toboh Gadang, dan Tuanku Qadi di Pakandangan. Ketujuh pilar tersebut merupakan refleksi representatif dari pemodelan dakwah kultural di Minangkabau.
\end{abstract}

Kata Kunci: sistem dakwah; kultural; tujuh pilar dakwah.

Received: Oktober 2021. Accepted: November 2021. Published: Desember 2021. 


\section{INTRODUCTION}

Syekh Burhanuddin was one of the charismatic Sufi figures and preachers who carried out Islamization in Minangkabau. He is considered successful in carrying out da'wah and laying the foundation for Islamic teachings in Indonesia, especially in the western part of the island of Sumatra. In the process, the internalization and dissemination of Islamic values brought and developed by Sheikh Burhanuddin always touch, adapt, compromise, and collaborate with local culture in the traditional structure of the local community. This process has become the distinctive feature of Sheikh Burhanuddin's da'wah movement in developing Islam and Muslims in Indonesia.

Syekh Burhanuddin is a great scholar from West Sumatra who was instrumental in developing the Syattariyyah Order. The teachings of this tarekat were adopted and obtained from their teachers, Ahmad al-Qushashi and Sheikh Abdurrauf Singkil in Aceh. This is evidenced by Syekh Burhanuddin's struggle artifacts, which can be seen from the discovery of the tomb complex, Tanjung Medan surau, Al-Qur'an, Islamic boarding schools, Islamic books, and kris, which are kept as cultural heritage to commemorate his da'wah struggle. Syekh Burhanuddin is seen as a scholar who can Islamize the Minangkabau community evenly and thoroughly (Arif, 2020).

One of the remains of Sheikh Burhanuddin that is remembered is the philosophy of life of the Minang people which states that "Adat basandi syarak, syarak basandi Kitabullah" (Islam must be the custom basis). This philosophy manifests Burhanuddin's sincerity in disseminating Islam in West Sumatra. In addition, the legacy services of the Minang Islamic process carried out by Burhanuddin can be viewed from the presence of physical buildings such as a surau where Syekh Burhanuddin's surau is made of wood and is the oldest surau which shows the existence of Islamization efforts in the Minang realm (Yunas, 2005).

Islamic architectural relics during Sheikh Burhanuddin are currently being developed into religious tourism areas that attract many visitors or pilgrims (Otari \& Fatimah, 2018). This shows that the impact of Syekh Burhanuddin's Islamization is significant. Thus, the historical legacy of his da'wah struggle has attracted the attention of many people from all over Indonesia, even in the world. Syekh Burhanuddin is a preacher who is committed and spreads Islam with various approaches, both culturally and 
structurally, to all people with various social backgrounds (Otari, Melay \& Ibrahim, 2016).

The activity of spreading Islam in the 15th century was inseparable from the role of Sheikh Burhanuddin Ulakan and his students (Syaripuddin, 1982). The spread of Islam that he carried out focused on systemic approach efforts by using community traditions as a medium of da'wah. The da'wah movement carried out with a cultural approach is a significant strength and potential in internalizing, diffusion, actualizing, and transforming society based on Islamic values. In this case, the cultural approach views da'wah as part of a sociological obligation that must be implemented into the main joints of community culture (Kusnawan \& Rustandi, 2021).

The cultural da'wah movement positions community culture as a space for actualizing Islamic da'wah, which must be in harmony with Islamic values (Masdini and Anggraeni 2020; Anwar and Mualimin 2019). Practically, the cultural da'wah approach is carried out by utilizing cultural expression spaces as a medium of da'wah, which is seen as effective in disseminating Islamic messages (Junita, Mualimin, and HM 2021; Mualimin et al., 2018).

Sociologically, culture is seen as an approach that focuses on a mixture of new cultures, contact zones, connectedness systems, and cultural identities (Sarwono, 2014). About da'wah, cultural da'wah is an effort to appreciate a culture that does not conflict with Islamic teachings and at the same time an effort to Islamize and use every existing culture to preach by dai individually or jointly through Islamic organizations and da'wah organizations. Abdullah also emphasized that cultural da'wah is an effort to instill Islamic values in all dimensions of life by paying attention to the potential and tendencies of humans as widely cultured creatures in realizing an actual Islamic society (Abdullah, 2012).

Da'wah, in its implementation, is not an activity in space. However, it is constantly dealing with social realities that will lead to a change and civilization that influences each other. Da'wah may be influenced by culture or vice versa. Da'wah contributes a lot to building a civilization and a systematic movement (harakah) through da'wah networks.

The network of student teachers (dakwah) in Islamic education (tabligh wa taklim) in Minangkabau started from the surau of Sheikh Burhanuddin in Ulakan (Firdaus, 2013). The surau is an educational center visited by many Minangkabau youths to study religion. The students came 
from coastal areas such as Ulakan, Pariaman, Padang, South Coast, Darek areas such as Luhak Tanah Datar, Luhak Agam, Luhak 50, Solok, and so on. Until now, the people of Ulakan Pariaman still survive and preserve the teachings that have been instilled by Sheikh Burhanuddin from generation to generation in cultural da'wah activities. Syekh Burhanuddin's cultural da'wah still exists and is preserved by his successors even though Sheikh Burhanuddin himself has died more or less 300 years or three centuries have passed. Therefore, it is necessary to deeply explore the system and pattern of cultural da'wah that was initiated and maintained to date.

Scientific discussions about Sheikh Burhanuddin have been widely studied by various academics, such as Syamsul Bahri Khatib (2012), researching the tarekat aspect as a source of Burhanuddin's da'wah movement. Firdaus (2013) about the Islamic education network in the XVII and XVIII Minangkabau Abat. Nova Sri Dewi, Hasanuddin, and Zulfadhli (2014) conducted a philological study of the transfer of literacy and language of historical texts of Islamization in Minangkabau conducted by Burhanuddin. Agustianda (2016) about Sheikh Burhanuddin's Sufism thoughts among the Minang people of Medan City. Aryanti (2017) provides an alternative model in developing religious tourism in the tomb area. It is strengthened by Hayati Otari and Siti Fatimah's (2018) research, which also analyzes the aspects of developing religious tourism in the tomb and heritage area of Sheikh Burhanuddin as well as Ridwan Arif's research (2020) which conducted a historical review of the central role of Sheikh Burhanuddin in Islamizing the people of West Sumatra.

This study uses two concepts or theories, namely systems theory and cycle theory in relation to cultural da'wah. Charles H Zastrow (1998: 16) calls it systems theory or systems theory. This concept is divided into three parts, namely the theory concept of wholeness, relationship, and homeostasis. Zastrow found that:

"The concept of wholless meens that the objects or elements within a system produce an entity that is greater than the additive sums of the separate psrts. Systems theory is antireducationistik; it asserts that no system cand by adecuately understood or totally explained once it has been broken down into its component part".

This expression describes the concept of wholeness, which holds that the system is the wholeness of the elements in a system that produces a larger entity from its separate parts. Systems theory is more antireductive. This concept also asserts that no system is adequate once broken down into 
various components. follows:

In addition, the concept of relations in systems theory is seen as

"The concept of relationship asserts that the patterning and structuring among the elements in a system are as informative as the elements themselves. The concept of homeostasis suggests that most living systems seek a balance to maintain and preserve the system".

The concept of relationship asserts that the patterns and arrangements among the elements in a system are as informants as the elements themselves. In comparison, the concept of homeostasis shows that most living systems seek a balance to maintain and preserve the system to give birth to something intended.

The system in the Indonesian context is interpreted as a device or elements that are interconnected between one system and another. So from the relationship between these elements can achieve a goal. Salmadanis (2003) reveals that there is a close relationship between the structure and the system from this meaning. In the structure, there are interrelated elements, so the system coordinates them so that the interrelated elements are coordinated into a single unit.

Based on this statement, it can be said that systems theories are specific concepts and views that discuss the relationship between elements that have relevance, attachment, and inclusion in a single meaning.

Amrullah Ahmad (1983) generalized the system to five components: input, conversion, output, feedback, and environment. The input component consists of three sub-systems: rew input, instrument input, and environmental input. The second component is called conversion, namely changing inputs into outputs in the sense of realizing Islamic teachings into socio-cultural realities that are processed in da'wah activities, including organization, management, leadership, communication, and so on. The next component is the output that changes the results of da'wah, namely the creation of a new reality according to the ideal size of the system based on the Qur'an and Al-Hadith. The feedback component can affect the da'wah system in particular and the socio-cultural reality in general. In comparison, the environmental component as a reality is to be changed.

The concept of cultural da'wah has two perspectives: first, compromise with culture, and second, firmness in determining the size and law of the existing cultural reality. Cultures contrary to Islam such as evil, heresy, superstition, and immorality are the targets of improvement 
through Islamic da'wah. Meanwhile, the prevention of munkar that is carried out individually, in groups, or through organizations must involve the community in an active and participatory manner. The implementation of Islamic da'wah must be relevant to the object's da'wah needs (Muhyiddin et al., 2014). This is related to the orientation of Islamic da'wah as an approach path in fostering personality so that they are submissive and obedient to the teachings of their religion (Thamrin, 2003: 3).

Culture is a set of attitudes, behaviors, and symbols shared by humans and is usually communicated from one generation to the next. Culture is not brought from birth but is passed down from generation to generation (Sarwono, 2014). Culture gives birth to various main aspects of human life, including religion. One of the essential aspects of religious teachings is the concept of da'wah. Da'wah is related to efforts to spread Islam in harmony with human activities. The da'wah approach places culture as a medium of da'wah in actualizing Islamic teachings.

Cultural da'wah is a da'wah that is carried out by following the local community's culture to ensure that its da'wah message can be received "without feeling" by the Madh'u (Ahmad, 2014). The cultural approach is very concerned about the potential of human tendencies as cultural beings so that da'wah activities are very flexible in creating a new culture with Islamic nuances. Cultural da'wah is carried out by utilizing local customs, traditions, arts, and culture.

Da'wah is a social change in which it is also culturally charged is not only done to convey messages but also to produce social change. At the individual level, social change is shown from the closer a person gets to Islamic values and practicing Islamic norms. Meanwhile, at the community level, social change is shown by the better social structure in the community where da'wah is carried out. The implications of Islamic da'wah can be realized through harmonious social relations where the social performance of the community is moving towards a direction that is increasingly in line with Islamic teachings (Ahmad, 2014). The estuary of this da'wah activity is manifested in the order of thought (frame of reference), actions, and actions (behavior) of the object of da'wah both on an individual scale and in society as a social community (Rustandi \& Hanifah, 2019).

Da'wah is broadly not only related to efforts to call, call, or plead but is also a planned activity of a da'i that is systematic, philosophical, methodical, and humanist. Da'wah is carried out verbally, in writing, and actual work (things) in growing and building awareness, understanding, 
understanding, appreciation, strengthening beliefs, changing living conditions and practice, and defending the values of Islamic teachings with specific methods and approaches to achieve goals-happiness, safety, and welfare of life in this world and the hereafter.

Da'wah is changing. Sociologically, Ibn Khaldun's concept of social change, known as the cycle theory, reveals that social change begins with a great civilization in a society that has been forged with a hard life, poverty, and full of struggle (Fajar, 2019). The desire to live prosperously and free from the hardships of life coupled with the existence of 'Ashabiyyah (solidarity bonds) among group members makes them strive to realize their ideas with hard struggle. The dream that was achieved then gave rise to a new civilization. The decline of another civilization usually follows this new civilization. These stages will be repeated, and so on, so this theory is known as the cycle theory. It can also be emphasized that history will repeat itself even though the names and places are different.

A culture occurs through various processes and the influence of the cycle of change in a civilization triggered by the intermingling of cultures. Where this assimilation includes the process of acculturation and assimilation. Acculturation is a process of cultural integration that produces a new culture without eliminating the original elements in the culture. Koentjaranigrat (2005) calls it cultural compounding, namely the acceptance of culture without surprise then the creation of a planned homogeny due to the similarity and similarity of cultural patterns. Then assimilation is defined as the process of assimilation between the two cultures accompanied by the loss of the characteristics of the original culture to give birth to a new culture through efforts to eliminate the differences between the two cultures.

Piotr Sztompka defines social change as a change in or includes different social systems under certain conditions in different periods. Changes in the social system can occur as a whole or only in part of the components triggered by the process of social change, such as essential elements, relationships between elements, functions, maintenance, subsystems, and the environment. The main elements include the number and types of individuals and actions. The relationship between elements is related to social ties, loyalty, integration, and relationships between individuals. Function dimensions are related to elements in the system, such as the role of individuals in carrying out their work-the maintenance of boundaries such as the conditions for acceptance of individual groups 
and recruitment principles in organizations. Sub-systems are concerned with the number and types of parts. The environment is related to natural conditions and geopolitical locations (Yazid, 2017: 11).

Change is a necessity that will happen. It is just that these events can be felt sooner or later, depending on how much influence the triggers cause. Of the six elements mentioned above, some will appear prominently or dominant, and some will only appear due to their relationship with the dominant element. One element will affect other elements because its existence is like being at a central point in a circle.

The process of forming and building culture cannot be separated into three processes, including assimilation, acculturation, and innovation (Wiranata, 2002). Assimilation is a process of cultural dynamics that occurs in society in the form of a combination or fusion of two or more cultures to give rise to a new culture without any element of coercion. Acculturation is the fusion of two or more cultures that give birth to a new culture (lost the old identity). Innovation is understood as a culture that is not influenced by foreign cultures but by human reforms.

This study aims to describe various information about the system and patterns of cultural da'wah by Sheikh Burhanuddin in Minangkabau. This research is helpful as initial information for scientists and da'wah practitioners in organizing and reducing friendly da'wah patterns, changing, and humanist through cultural approaches as the implementation of Rahmatan lil alamin da'wah.

This study uses a qualitative historical approach. Historical research is divided into four dominant directions: comparative, juridical, biographical, and bibliographical (Harahap, 2011). This research explicitly uses a biographical and bibliographical approach. Biography deals with a character's life with society, the characteristics, character, thoughts, and ideas of a character. Bibliography deals with documents in the form of works and research results related to the characters being studied to reveal events, phenomena, and data about Syekh Burhanuddin Ulakan with cultural da'wah activities and specifically to dig up information about the structure and system of da'wah. The culture.

This research aims to describe field data through observation, interviews, and documentation studies. Observation models used are nonparticipant and semi-structured interviews and studies of manuscripts and other historical relics of the characters. The research was carried out in Ulakan Pariaman as a center for the growth and development of cultural 
da'wah and then equipped with areas where the development of cultural da'wah was carried out by friends, companions, and students of Sheikh Burhanuddin. The locations include Pariaman, Pesisir Selatan, Solok, the city of Padang, and Batu Cage.

Using a snowball sampling approach, data collection was carried out by utilizing key informants and network systems in the research. The implementation of the snowball concept begins with looking for critical informants and then completing and refining the data according to the needs-based recommendations that are rolling until data saturation is found. Figures relevant to the da'wah produced by Sheikh Burhanuddin. Then do field observations about the legacy of the figures and conduct interviews with community leaders to obtain information about the character of Sheikh Burhanuddin Ulakan, who specifically examines the cultural da'wah system.

The data analysis procedure was carried out through several stages of activities, including finding specific patterns, looking for the relationship between the thoughts of the figures and the cultural da'wah movement, giving meaning, and classifying actions, actions, and attitudes as well as community responses to the policies of the figures, generalizing ideas, and describing each finding in narrative form. It was alternatively deciphering the results of a critical study of a character in words that can be read.

\section{RESULTS AND DISCUSSION}

\section{A Brief History of Sheikh Burhanuddin Ulakan}

Syekh Burhanuddin was born in Guguak Sikaladi Village, Pariangan Tanah Datar near Padang Panjang, on 11 Syafar 1026 H/1606M. He died on Wednesday the 10th of Syafar in 1111 Hijrah / 1704 AD. His surname was Kinun, and some people knew him as Pono. Kinun or Pono, after studying religion with Sheikh Abdullah Arif (Tuangku Medina) he was nicknamed Pakih Sampono (Pono). His father's name is Pampak of the Koto ethnicity, and his mother's name is Cukuik of the Guci tribe.

Syekh Burhanuddin had several teachers, such as Sheikh Abdullah Arif (Tuangku Medina) or Abdul Khair Abdullah Arif, a Maliki school of thought, and Abdurrauf Singkil, who was a Shafi'i school of thought. Meanwhile, Abdurrauf's teacher was Ahmad al-Qasyasyi in Medina. Syekh Burhanuddin is more popularly known as a Sufi figure with the Syatariyah sect with the Syafi i school of thought (Tengku Eri Firmansyah: interview: August 22, 2021). 
There are several opinions regarding the surname of Sheikh Burhanuddin. First, "Buyuang Panuah" (full boys, enough, or already established). Second, Burhanuddin has the nickname "Buyuang Pono" which stands for "Samparono" (perfect). Third, Imam Maulana, in his book Muballighul Islam mentions Burhanuddin's first name as "Qanun" (Azra, 1988). The dynamics of Sheikh Burhanuddin's Islamic intellectuality occurred since childhood. Where Sheikh Burhanuddin received moral education and character from his parents. Then, historical records state that Sheikh Burhanuddin studied no less than 30 years with several of his teachers, especially with Sheikh Abdurrauf Al-Fanshuri. In 1680, Sheikh Burhanuddin returned to Minangkabau. Furthermore, before his return, Sheikh Abdurrauf gave him Burhanuddin'. Since then, Pono or Kinun has carried the name Burhanuddin. His return was released by his teacher, Sheikh Abdurrauf, and witnessed by several of his friends and several officials of the Aceh Sultanate (Samad, 2003).

Arriving in Minangkabau, Sheikh Burhanuddin chose the Ulakan area to center his da'wah activities. Burhanuddin carried out the Islamization efforts with several students and followers. In this place, Burhanuddin established a surau in the Tanjung Medan area of Ulakan. In historical records, a Ulakan area is a historical place that displays the historical value and evidence of the spread of Islam in Minangkabau (Arif, 2020).

Syekh Burhanuddin's study trip in Aceh set him up to meet his four friends who came from Shadow Tarusan, Kubang Tigabelas, Padang Ganting, and Batu Hampar (Otari, Melay \& Ibrahim, 2016). The four friends were named Maruhun Panjang, Tarapang, Matnasir, and Buyung Mudo. He was told in the ancient manuscript version of Imam Maulana Abdul Manaf Amin Al-Khatib (1993) that the four friends initially did not know the direction and purpose. So he finally met with Sheikh Burhanuddin and eventually followed him to study with Sheikh Abdurrauf in Aceh (Dewi, Hasanuddin \& Zulfadhli, 2014). It was these four friends who accompanied Burhanuddin during his studies as well as influenced the learning process he was doing.

Other historical records show various tests experienced by Burhanuddin while studying with Sheikh Abdurrauf. It was even told that his teacher deliberately brought the test to forge Burhanuddin as a preacher. The test is related to the physical, mental, commitment test, to the most challenging test related to lust or lust. In historical records, it was stated that Burhanuddin's most demanding test was when his teacher ordered him 
to live in his house with two girls who were his teacher's daughters. This is the test of Burhanuddin's faith in maintaining his lust. This test led Burhanuddin to gain the trust, and at the same time, he was deemed to have passed by his teacher. Thus, Burhanuddin was ordered to return to his village immediately and spread the message of Islam there (Dewi, Hasanuddin \& Zulfadhli, 2014; Otari, Melay \& Ibrahim, 2016).

The pattern of Sheikh Burhanuddin's religious understanding cannot be traced with certainty. This is related to the lack of essays that reflect his teachings and thoughts. It is just that when referring to the religious understanding of his teacher, Sheikh Abdurrauf, then Burhanuddin follows the Ahlu Sunnah wa al-jamaah in i'tiqad, the Shafi'i school in fiqh, and the Syattariyyah congregation in Sufism (Arif, 2020). In turn, this pattern of understanding influences the mindset and way of preaching, especially concerning cultural approaches. The cultural da'wah approach became the pattern of da'wah activities carried out by Sheikh Burhanuddin in Minangkabau.

\section{History of Syekh Burhanuddin's Da'wah}

Syekh Burhanuddin's da'wah (Pono alias Kinun) began studying with Sheikh Abdul Khair Abdullah Arif, or Yahyudin (a title given by the king in the Maldives) in Minangkabau dubbed Pourku Madinah in Kenagarian Sungai Gimba, which was formerly known as Batang Gasi. The term Gimba is the name for mentioning neem or pulpit by the local community. The gimba became the seat of the Tuanku Medina preaching to teach Pono or Kinun and Tuanku Idris Majolelo and other people with da'wah materials in the form of Tawhid and Sufism (Interview with DB).

After studying with Tuanku Medina, he continued with Sheikh Abdurrauf Singkil in Aceh together with four other friends, namely Buyung Mudo Puluik-pulik from the South Coast, Muhammad Natsir from Koto Tangah Padang, Mukhsin from Agarng Solok, and Maruhun Nan Panjang from Padanggantiang Tanah Datar (interview with: Tuanku Heri Firman Syah). After studying with Sheikh Abdurrauf Singkil on instructions from his teacher Ahmad Qashasyi in Medina, Pono was given the title of Sheikh Burhanuddin before returning to the Minang realm to carry out da'wah. Mahyudin, community leader VII Koto, in his statement, likened Pono to studying in Minang with Tuanku Medina and being graduated in Aceh by his teacher Abdurrauf Singkil whose title had been prepared by his teacher in Medina. 
At least, some of the da'wah patterns carried out by Sheikh Burhanuddin in the Islamization effort in Minangkabau, among others: first, establishing a base for the da'wah movement in the form of an education center. He established a surau as a center for da'wah and educational activities. Surau was founded when Burhanuddin returned to Minangkabau. With the help of his friend, Idris, a preacher of Majolelo, Burhanuddin established a surau in Tanjung Medan, Ulakan. The surau has become an artifact of Burhanuddin's da'wah that many Muslims visit (Yunas, 2005; Azra, 2000; Daya, 1990; Fathurahman, 2010).

Second, Islamization in Minangkabau was carried out by Burhanuddin using a Sufism approach. This is done by utilizing the local community's traditions, arts, customs, and culture (Hamka, 2010; Fathurahman, 2010). Burhanuddin's wisdom approaches include: (a) Islamizing the youth through the games of the country's children. This is done by habituation of saying bismillah when starting the game; (b) participating in national children's games such as playing kites. This is done so that it is easy to interact with various levels of society; (c) preaching Islam gradually through harmonization of religion with culture. For example, Tuanku, Imam, Khatib, and Labai are tangible manifestations of syarak and local culture (Arif, 2020).

Third, combining Islam with local culture. This became the pattern of Sheikh Burhanuddin's da'wah movement in disseminating Islam in society. Burhanuddin is seen as capable of integrating adat with his sociocultural life. This is Burhanuddin's masterpiece in Islamizing society (Samad, 2003). This approach is carried out by diffusing Islamic teachings into Minangkabau customs. For him, Minang customs are related to character and morals. Therefore, Burhanuddin incorporated Islamic values into the traditions and customs of the Minang community such as children's games, martial arts, philosophy of life, and so on.

Some of the approaches above are the joints of cultural da'wah carried out by Burhanuddin in the Islamization of society in Minang. This can be seen from the cultural da'wah system implemented by Burhanuddin. For example, in the input component, Burhanuddin emphasized the importance of understanding local customs and culture in the process of Islamizing the community. The conversion component is carried out by incorporating the values of Islamic teachings in several aspects of community culture. The output component is by realizing the values of Islamic teachings, especially those related to morals and character in the 
habits of the Minang people. Components of the environment and feedback display exemplary attitudes based on Islamic values, one of which is the Minang philosophy which states the adat of the syarak, the syarak basandi, the Kitabullah.

\section{Multi-Level Da'wah as a Burhanuddin Cultural Da'wah System}

Syekh Burhanuddin's Cultural Da'wah can be said to adhere to a multi-level marketing and integrative system that adapts to the character and culture of the Minangkabau community. In this case, da'wah activities are carried out in stages and stages. The first level, da'wah, is influential people from among the kings and rulers and spiritual figures or religious leaders. Da'wah's second level is done through friends and comrades in arms. Moreover, the third level, da'wah, is carried out through a cadre process in a wooden surau known as the Tuo surau.

The integration of the da'wah system carried out by Sheikh Burhanuddin is by combining adat and syara, so that there is no clash between custom and religion. This can be seen from the way and lifestyle of the community and the ornaments of houses of worship whose designs are unified. This ornament is called surau Bagonjong. In addition, Sheikh Burhanuddin's cultural da'wah still has a sanad and network of da'i and madh'u, which are still strong and maintained and preserved by his followers until now.

The results of interviews and manuscripts and a study of the genealogy of Syekh Burhanuddin's da'wah found that the first da'wah activity was carried out with the closest person, namely a friend from a university known as Idris Pourku Majolelo. An informant (DB, 71 years old) revealed that on August 17, 2021, one of the traditional leaders of Tapakih mentioned that Idris Pourku Majolelo was the first person to bring Syekh Burhanuddin to preach to the kings of Minangkabau.

Another informant, (Tuangku Heri Firmansyah at Surau Clothing) stated that after returning to Minangkabau, Syekh Burhanuddin was accompanied by Tengku Idris to develop da'wah, especially in Tanjung Medan, known as Surau Tuo Tanjong Medan, also known as Surau Kayu. It was at the surau that Syekh Burhanuddin carried out cadre of da'wah and guidance for the people who came from various corners of the country such as Padang, Pesisir Selatan, Agam, Solok, and Batu Sangkar. This includes comrades in arms such as Muhammad Nasir Surah Baru Koto Tangah Padang, Muhsin Agarng, Solok Regency, Makhudum from Padang 
Ganting Tanah Datar, and Buyung Modo Puluik-puluik Bayang Pesisir Selatan.

His da'wah activities also involved the kings in Tapakis to spread da'wah to Pagaruyung. Sheikh Burhanuddin was accompanied by several kings such as Rajo Sampono (Rajo Kataping), Rajo Basa, Sutan Basa, Malako, Malakewi, and Rangkayo Batuah (Rajo Tapakih). After Sheikh Burhanuddin succeeded in carrying out Da'wah at the Pagaruyung Palace, the King of Pagaruyung named Rajo Alif embraced Islam. After that, the da'wah began to spread to the indigenous people and agreed on the Bukik Marapalam inscription. The contents of this inscription are "Basandi Syarak custom, Syarak basandi Kitabullab". Where da'wah activities are carried out in the form of halaqah.

DB (71) found that coaching activities were carried out to cadre the best sons from each kingdom or ruling kings to be educated in religious knowledge. After that, they were returned to each kingdom as Pandito. Pandito is a term for religious leaders who are clever and agile in giving speeches. Then in its development, it turned into Malin Pandito. These envoys eventually spread to become the pillars of da'wah known as the Seven Pillars of Da'wah Syattariyyah.

The seven pillars that support da'wah are found in various regions, which support and strengthen the joints of cultural da'wah. Each region has figures who play an essential role in da'wah activities. The seven pillars are: Sheikh Tuo in Koto Tuo Religion District, Tuanku Qadhi in Lubuk Ipuh, Tuanku Kali in seven Koto, Tuanku Qadhi Koto Gadang, Ampu Syarak in Sintuak, Tuanku Qadhi in Koto Gadang, and Tuanku Qadhi Toboh Gadang and Pourku Qadi sometimes.

The duty and authority of Sheikh Tuo Koto Tuo are to be an advisor and a place to ask other Tengku-Tengku about syara matters. Tuanku Qadhi Lubuk Ipoh is the place to make final decisions on traditional and religious affairs. Pourku Kali Tujuh Koto, becomes the center for making decisions or a deliberation institution and a center for religious activities. He was the first to initiate religious ritual activities that other regions would follow. Meanwhile, Sintuak is known as Anpu Syarak or the parent of syarak because this is where religious information includes the genealogy of Sheikh Burhanuddin's preaching activities. Angkor Kuning (61 years old) stated that Ampu Syarak is a term for syarak baampu. Baampu means having a parent, genealogy, and a teacher's sanad who has students hereditary from Sheikh Burhanuddin (Inyiak Syiyah). 
The relationship between the seven pillars is illustrated by the activities when entering the month of Ramadan and other Islamic holidays. Where, on the instructions of Sheikh Tuo to the other pillars to perform ru yatul hilal. When it was known that there was a new moon, the information was conveyed to Sheikh Tuo Koto Tuo. Then this information was brought to Ulakan Tapakih for Deliberation. The Deliberation results were rounded up and given arguments in the Seven Koto. If there is a unanimous decision, then the decision is taken to Lubuk Ipuh to be determined (Puncung Putiah, Liang Tabuk). It is used as a guideline. Then after it was decided, the sound of the prohibition drum (drum) located at the Seven Koto Grand Mosque, Padang Pariaman was followed by each Surau in the Minang realm. Including religious activities such as the prophet's birthday starting from the Seven Koto Village for two days and continued by each surau in the Seven Koto Village to carry out the birthday in three months.

Labay Abdurrasyid (68 years old), as the assistant of Tuanku Qadi Lubuk Ipuh stated that Lubuk Ipuh was the place where kings made decisions, so the term "Kungkuang in Ulakan, Kabek Arek in Tujuh Koto and Pancung Putiah Biang Cabik arose in Lubuk Ipuh". Labay also explained that Lubuk Ipuh is the last place for a decision to be made that will be implemented in the community. The principle of decision-making is "Kandua Badanting-datiang, Tagang Bajelo-jelo," the decision is passed through deliberation in Ulakan. The decision results are brought to the Seven Koto to be strengthened and tightly bound. The final decision is carried out at the Tuanku Qadi surau Lubuk Ipuh, characterized by the Bagonjong surau.

If you look closely, the structure and hierarchy of Sheikh Burhanuddin's cultural da'wah will find integration between adat and syarak. In the Minang community, especially in Kenagarian Tujuh Koto, two influential kings were found: the king of adat and worship. The traditional king is in charge of customs affairs (in Balerong) and the king of worship is in charge of religious affairs (in Langkan). Both of them were under the leadership of Angku Kali Tujuh Koto, whom Katik and Labay assisted. Everything is integrated and implemented at the Great Mosque of Kenagarian Tujuh Koto.

This kind of da'wah pattern has been felt helpful by the community from generation to generation to this day. Angku H. Islamil Tuanku Kuning (71 years old), former Angku Kali Kanagarian Lubuk Pandan, in 
his surau said that we have been following and preserving the da'wah values instilled by Sheikh Burhanuddin from generation to generation. Here, religious activities are carried out by Labay whom Tuanku and Katik assist. In the state's life, Labay's position is under traditional leadership. Each surau has one Labay and one Ninik Mamak. Labay and Pourku carry out Da'wah activities in each of the people's surau. Therefore, it is not surprising that in Lubuk Pandan there are 24 people's surau according to the number of tribes. Pourku Kuning also emphasized that with the preaching system of Sheikh Burhanuddin developed by the Labays, under the supervision of the customary leaders of the children of the nephews in Kenagarian, they were protected and protected from various violations such as theft and moral violations.

\section{CONCLUSION}

Syekh Burhanuddin's model of cultural da'wah is carried out using the Multi-Level Da'wah (MLD) system. This is reflected in the interrelationships between the components of its da'wah. In the input component, Burhanuddin emphasized the importance of understanding local customs and culture to convert the community. The conversion component is carried out by incorporating the values of Islamic teachings in several aspects of community culture. The output component is by realizing the values of Islamic teachings, especially those related to morals and character in the habits of the Minang people. Components of the environment and feedback display exemplary attitudes based on Islamic values, one of which is the Minang philosophy which states the adat of the syarak, the syarak basandi, the Kitabullah.

This research has only found historical evidence and the da'wah model Sheikh Burhanuddin and his followers. In Minangkabau, word-ofmouth stories are reinforced by incomplete historical relics through opinion polls. Therefore, the writer recommends that the following researchers actualize and revitalize Sheikh Burhanduddin's cultural da'wah models in the present context to preserve the rahmatan lil alamin in the Minang realm.

In addition, efforts to develop the tomb area and architectural relics of Sheikh Burhanuddin's Islamic missionary struggle must be renovated to become a religious tourism area. In addition, the maintenance of valuable sites related to Religious Cultural Conservation is essential to save and maintain the remains of religious leaders so that they become ibrah and 
historical evidence for future generations.

\section{REFERENCES}

Abdullah. (2012). Dakwah Kultural dan Struktural Telaab Pemikiran dan Perjuangan Dakwah Hamka dan M. Natsir. Bandung: Citapustaka Media Perintis

Agustianda. (2016). Permikiran Tasauf Syaikh Burhanuddin di Kalangan Masyarakat Minang Kota Medan, Tesis, Medan: Program Pascasarjana UIN Sumatera Utara.

Ahmad, A. (1983). Dakwah Islam dan Perubahan Sosial. Yogyakarta: Primaduta.

Ahmad, I. (2014). Pendekatan dan Metodologi Penelitian Dakwah dalam Kajian Dakwah Multiperspektif: Teori, Metodologi, Problem dan Aplikasi. Bandung: PT. Remaja Rosdakarya.

Arif, R. (2020). Sejarah Islamisasi Minangkabau: Studi terhadap Peran Sentral Syekh Burhanuddin Ulakan, IJIHC: Indonesian Journal of Islmic History and Culture, 1(2), 122-136. DOI: https://doi.org/10.22373/ijihc.v1i2.620.

Aryanti, D. (2017). Model Pengembangan Kawasan Makam Syekh Burhanuddin sebagai Kawasan Religi, Jurnal REKAYASA, 7(2), 027042.

https://jurnalrekayasa.bunghatta.ac.id/index.php/JRFTSP/article/ download/6/4.

Azra, A. (1988). Jaringan Ulama Timur Tengah dan Kepulauan Nusantara Abad XVII dan XVIII. Bandung: Mizan.

Daya, B. (1990). Gerakan Pembaharuan Pemikiran Islam: Kasus Sumatera Tawalib. Yogyakarta: Tiara Wacana Yogya.

Dewi, N. S., Hasanuddin., \& Zulfadhli. (2014). Alih Aksara dan Alih Bahasa Teks Sejarah Ringkas Auliyaullahusshalihin Syekh Burhanuddin Ulakan yang Mengembangkan Agama Islam di Daerah Minangkabau Versi Imam Maulana Abdul Manaf Amin Al-Khatib, Jurnal Bahasa dan Sastra, 2(2), 1-15. https://garuda.kemdikbud.go.id/documents/detail/1807391.

Fajar, A. S. M. (2019). Perspektif Ibnu Khaldun Tentang Perubahan Sosial, Jurnal Sosial Budaya Syar'I, 6(1), 1-12. DOI: https://doi.org/10.15408/sjsbs.v6i1.10460.

Fathurahman, O. (2010). Tarekat Syattariyah di Minangkabau: Teks dan Konteks. Jakarta: Prenada Media Group. Ecole Francaise D'extreme- 
Nazirman., Saharman., \& Abdulmanan Sihombing

Orient. Pusat Pengkajian Islam dan Masyarakat (PPIM) UIN Jakarta, KITLV Jakarta.

Firdaus. (2013). Jaringan Pendidikan Islam di Minag Kabau Abad XVII dan XVIIIM, Disertasi, Padang: Program Pascasarjana IAIN Imam Bonjol Padang.

Hamka. 2010. Ayabku: Riwayat Hidup Dr. H. Abdul Karim Amrullah dan Perjuangan Kaum Agama di Sumatera. Shah Alam: Pustaka Dini.

Junita., Mualimin., \& HM. (2021). Dakwah Kultural Dalam Tradisi Maantar Jujuran Suku Banjar Di Samuda Kotawaringin Timur, Jurnal Dakwah Risalah, 31 (2): 138-53. https://doi.org/10.24014/jdr.v31i2.10581.

Koentjaraningrat. (2005). Pengantar Antropologi II Pokok-Pokok Etnografi, Jakarta: Rineka Cipta.

Kusnawan, A., \& Rustandi, R. (2021). Menemukan Moderasi Beragama dalam Kaderisasi Dakwah: Kajian pada Pemuda Persatuan Islam Jawa Barat, NALAR: Jurnal Peradaban dan Pemikiran Islam, 5(1), 4161. DOI: 10.23971/njppi.v5i1.2900.

Mahyudin, H. Y. (2001). Islam di Alam Melayu. Kuala Lumpur: Dewan Bahasa dan Pustaka.

Mualimin., Yunaldi, A.,, Sunandar, dan Alkadri. (2018). Cultural Da'wah of Antar Pinang Pulang Memulangkan Tradition in Sambas Malay Society, West Kalimantan, Ilmu Dakwah: Academic Journal for Homiletic Studies, 12 (2): 201-2013. https://doi.org/10.15575/idajhs.v12i2.1909.

Muhyiddin, A. dkk. (2014). Dakwah Perspektif al-Quran, Kajian Dakwah Multiperspektif: Teori, Metodologi, Problem, dan Aplikeasi. Bandung: Remaja Rosdakarya.

Otari, H., \& Fatimah, S. (2018). Development of Rilegiios Tourizm and History of Complex Syekh Burhanuddin Tomes in Ulakan, District Padang Pariaman, JPPI ( Jurnal Penelitian Pendidikan Indonesia), 4(2), 139-142. DOI : https://doi.org/10.29210/02018285.

Otari, H., Melay, R., \& Ibrahim, B. (2014). Syekh Burhanuddin Role in Developing the Islamic Religion in The Villages Ulakan Districts Ulakan Tapakis District Padang Pariaman (1683-1704), Jurnal Online Mahasiswa Fakultas Keguruan dan Pendidikan, 3(2), 1-9. https://jom.unri.ac.id/index.php/JOMFKIP/article/view/10839/ 10494.

Rustandi, R., \& Hanifah, H. (2019). Dinamika Dakwah Komunitas Remaja Islam di Kecamatan Pangalengan, ANID A (Aktualisasi Nuansa Ilmu 
Dakwah), 19(2), 199-224. DOI :10.15575/anida.v19i2.7540.

Samad, D. (2003). Syekh Burhanuddin Ulakan dan Islamisasi di Minangkabau: Syarak Mendaki Adat Menurun. Jakarta: The Minangkabau Foundation.

Sarwono, S. W. (2014). Psikologi Lintas Budaya. Jakarta: PT. Raja Grafindo Persada.

Shaghir, A. (1996). Tafsir Puisi Hamzah Fansuri dan Karya-Karya Sufi. Kuala Lumpur: Khazanah Fathaniah.

Thamrin, H. et.all. (2003). Peta Dakwah Kota Pekanbaru, Kekuatan, Kelemahan, Peluang dan Ancaman. Balitbang MUI.

Wiranata, I. G. A. B. (2002). Antropologi Budaya. Badung: Citra Aditia Bakti.

Yazid, Y., \& da Alhidayatillah, N. (2017). Dakwah dan Perubahan Sosial. Depok: PT. Rajagrafindo.

Yunas, M. N. (2005). Peran Surau Syaikh Burhanuddin sebagai Lembaga Pendidikan Islam Tradisional di Pariaman Sumatera Barat, Jurnal Penelitian dan Evaluasi Pendidikan, 7(2), 209-224. DOI: $0.21831 /$ pep.v7i2.2021. 
